\title{
Analysis of Residents' Satisfaction Levels with Housing and Residential Environment of Six Occupied Housing Estates in Benin City, Edo State, Nigeria
}

\author{
Kingsley Okechukwu Dimuna \\ Department of Architecture, \\ Ambrose Alli University, \\ Ekpoma, Nigeria \\ Abiodun Olukayode Olotuah \\ Department of Architecture, \\ Federal University of Technology, \\ Akure, Nigeria
}

Doi: 10.36941/ajis-202o-0o16

\begin{abstract}
Poor housing and poor environmental quality have been associated with adverse effects on health of residents and their quality of life, emotional and psychological well-being. The quality of housing and building environment is therefore essential for residents' residential satisfaction. This study analysises and examines the satisfaction levels of residents with housing and neighbourhood /building environment of six occupied housing estates in Benin City, Edo state, Nigeria. Data were collected in 2018 from six (6) housing estates located at; Oluku, Ugbowo, Oregbeni, Ikpoba Hill, Iyekogba-Ebo and Evbuoriaria. The data was obtained from sources within the study area using questionnaires, personal interviews and physical observations. The statistical tools used for analysis of data include: means, standard deviations, and categorical regression analysis. The results showed that there are variations in Relative Satisfaction Index (RSI) scores across the environmental dimensions examined for both the older and relatively newer estates. For the relatively newer estates such as Iyekogba, Oluku and Andrew Wilson result revealed that the residents are quite satisfied with Allocation for Recreation Centre (RCT) and Condition of Overcrowding (CO) with RSI scores ranging from 3.00-4.711; while those for the older estates such as Ikpoba Hill, BDPA and Oregbeni also appeared fairly satisfied 3.0o-3.5. Regarding Condition of Overcrowding (CO), Refuse Disposal (RD), Level of Noise Pollution (LNP), Clean Kept Surrounding (CKS), Erosion Effect (EE), and Quality of Water $(Q W)$. Findings further revealed that RSI scores for the residents in Iyekogba, Andrew Wilson and Oluku are ranked higher indicating better satisfaction levels when compared to the RSI scores for the older estates. The results of Categorical Regression Analysis revealed that the estates environmental indicators impact positively and significantly at 5 percent $(p=0.003)$ on the satisfaction levels of residents. Hence efforts at improving environment of the state will directly influence residents' satisfaction. Some measures that could enhance the quality of building environment and hence the satisfaction of residents were recommended. The study concludes that good planning and management of public housing estates are very vital because living in a decent housing and environment would lead to residents' higher satisfaction level.
\end{abstract}

Keyword: Housing, Building Environment, Residential Satisfaction, Relative Satisfaction Index (RSI) 


\section{Introduction}

Housing and the housing environment connotes different meanings and understanding to different scholars. These varied concepts and definitions arose as a result of different perspectives which different researchers have used to study housing and its environment. These concepts revolve around housing and housing environment as being made up of not merely of the physical shell (the house) ,but to certain extent covers all the ancillary provisions and communal amenities that are essential for human wellbeing (WHO, 1961;UN, 1975; Akinbode, 2000; Agbola, 2005; Aluko, 2012). In this regards, housing in its wide understanding in addition to the shelter element, include the community facilities social amenities and services as well as those equipments and devices that are vital to social well being and physical health of the inhabitants, hence is fundamental to their satisfaction (UNCHS, 2001; WHO, 2006; Olatubura \& Adegoke 2007 \& Henilane, 2016).

The Nigeria Housing Policy (NHP, 2006), which articulates the path to the nation's development in housing, emphasizes human settlement for better quality of living; adequate, decent and affordable housing, national integration and unity. Corroborating this, Ibem \& Aduwo (2013), acknowledge that the overall aim of every public housing in Nigeria has been geared towards providing home dwellers and users with houses that meet their needs, aspirations and expectations and at same time are in line with standard of quality prescribed by government. However, UNHABITAT (2006) Report cited in Ibem \& Aduwo (2013), argue that regardless of Nigeria government's commitment and noble efforts to make available decent and adequate housing; public housing, the nation has failed to realise this goal. This could be attributed to the fact that many years of government direct involvement and in participation in housing have concentrated efforts on quantitative aspect of housing to the neglect of qualitative aspect, such as housing quality, users' tastes and satisfaction (Ukoha \& Beamish, 1997; Olotuah, 2000; Mabogunje, 2003;).

The nature or quality of immediate neighbourhood is very important for residents' housing and residential satisfaction. This is so, as unattractive, dirty and uncared for, depressing of surrounding and unplanned neighbourhood can contribute immensely to great personal and family dissatisfaction and apathy (Gbakeji, 2014). This dissatisfaction induced by poor planning of the built environment, poor housing and environmental conditions have been found to be associated with stress that often led to juvenile delinquency, poor jobs and social performances, family disorganisation and in some cases deviant behaviours. These socially deleterious circumstances are often present in, and are even characteristics of; parts of any city where there are unsatisfactory housing conditions (Asikhia \& Ajirioghene, 2012). Similarly, (Gbakeji, 2014) identified residential and building environment as important indicators of housing quality and explained that these significantly have an effect on residents' quality of life and hence their satisfaction. Substantiating this view, Dimuna (2017) asserts that the satisfaction which residents derive as a result of the quality of the housing and residential environment is very vital for their overall housing satisfaction.

Findings of a number of studies on housing have continued to demonstrate that poor environmental quality has very serious adverse effects individual's quality on the social, economic, emotional and psychological well-being of people (Ibem \& Azuh, 2014; Ibem \& Aduwa, 2013, Olotuah, 2002; Gbakeji, 2006); and hence their satisfaction (Dimuna,2017).

Satisfaction with housing in the view of (Akindele, Tosin \& Abolade, 2014), happens whenever neighbourhood and housing situations meet with cultural, family and community housing norms. Corroborating this view, Olatubara \& Fatoye (2006) posits that residential housing satisfaction is when housing norms meet the residents/occupants considerations of what their ideal dwelling units ought to be and how the residents assume that these housing and building environment will help them actualize their housing desires. On one hand, this understanding of housing satisfaction would mean that the needs of the residents have been accomplished and the occupants are contended in their dwelling units or homes. On the Other hand, dissatisfaction would mean discontentment of residents with their housing provisions or neighbourhood environment. Mohit, Ibrahim \& Rashid, (2010) argue that dissatisfaction in housing could results in residents desire to look for alternatives by moving from one 
neighbourhood to another or making structural adjustments to their residences. They further opine that where there is no opportunity to achieve any of these alternatives, would lead to chronic dissatisfaction.

This study examines and analyses residents' satisfaction levels with housing and residential or building environment in six occupied housing estates in Benin City, Edo State, Nigeria. The specific objectives are to: (i) Identify and examine the variables and indicators that determine levels of residents' satisfaction with housing and neighbourhood environmental sub-system in six public housing estates;(ii) Determine if differences exist in the levels of satisfaction in the different public housing estates;(iii) Compute Relative Satisfaction Indices (RSI) for each of the public housing estates; and (iv) Recommend measures that can improve and enhance the levels of residents' building environment housing satisfaction across the six public housing estates.

\section{Study Area}

Benin City is the specific area of study. The city is the capital of Edo State of Nigeria; as well as the administrative headquarters of Oredo Local Government Area. There are three local government areas namely: Oredo, Egor and Ikpoba Okha that make up Benin City. As a result of this strategic political relevance, there is an increase in the tempo of socio-economic development. Many industries, factories and other employment centres have sprang up. In addition, the construction of the Benin Bye-pass around 1999 to 2002, that is now a major traffic corridor to other neighbouring states has led to increase spatial expansion and physical developments. The sum total is that urbanization is moving towards neighbouring towns in other local government areas such as Oluku in Ovia South West and Egba in Uhunmwunde Local Government Areas as shown in Figure 1.

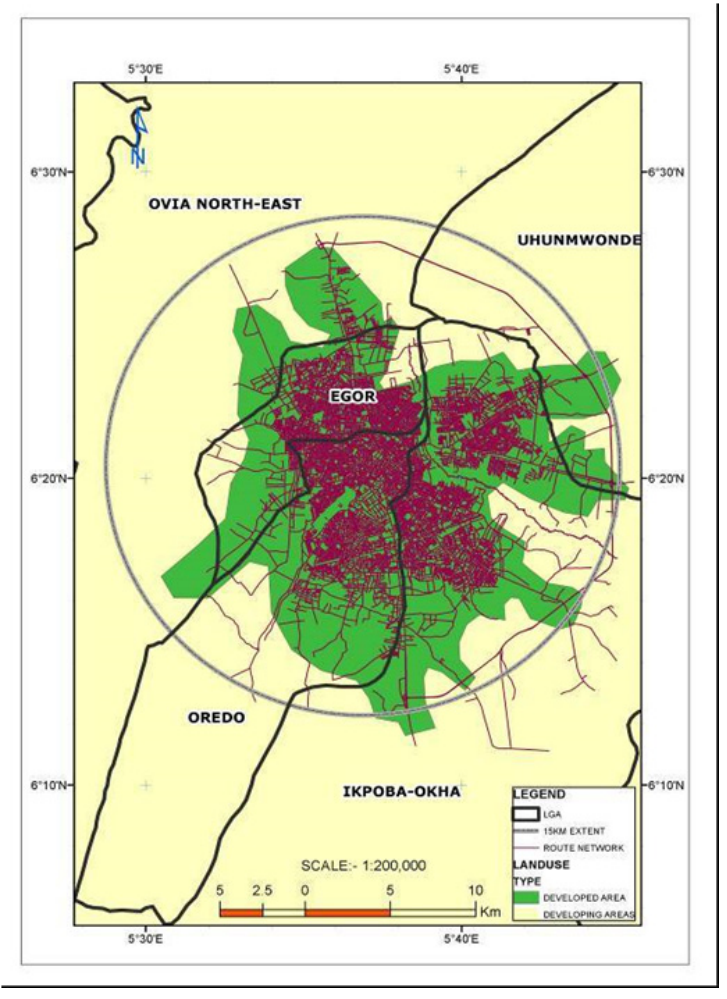

Figure 1: Map showing the $15 \mathrm{Km}$ Extent of Benin City

Source: Edo State Geographical Information Services (2019) 
Benin City geographically lies within the Latitude $6^{\circ} 20^{\prime}$ and $6^{\circ} 31^{\prime}$ North of the equator and Longitude $5^{\circ} 32^{\prime}$ and $5^{\circ} 41^{\prime}$ East. It has a landmass of 112.5 square kilometres. The city lies within the southern zone of Nigeria and falls within the tropical zone.

Historically, Benin City was also the capital of ancient Benin Kingdom, which prospered between the 14th and 17th century. Then, the Oba exercised great influence in secular (traditional) affairs and civil administration (The Columbia Encyclopaedia, 2007). At its peak or zenith, Benin Kingdom stretched from the Republic of Benin (Dahomey) in the West to the Niger Delta (Onitsha) in the East (The Columbia Encyclopaedia, 2007).

Benin City had a population of 53,753 in 1952 national census. In the 1963 national census the city almost doubled its population and recorded 100,693. In 1991 National Census, the population of the city rose to 780,976 (National Population Commission, 1991); which showed a rapid increase in the population of the city. According to data from the National Population Commission (2006), the population of Benin City in the last national census in 2006 is 1,346,703.

The economy of Benin City is enhanced by industrial and commercial activities making the city the most urbanised town in Edo State. Benin City is also the seat of State Government and the Oredo Local Government. These dual roles have attracted large number of people to the City; and impacted on housing and environmental quality of the city. The study area covers the six selected and occupied public housing estates shown in Figure 2.

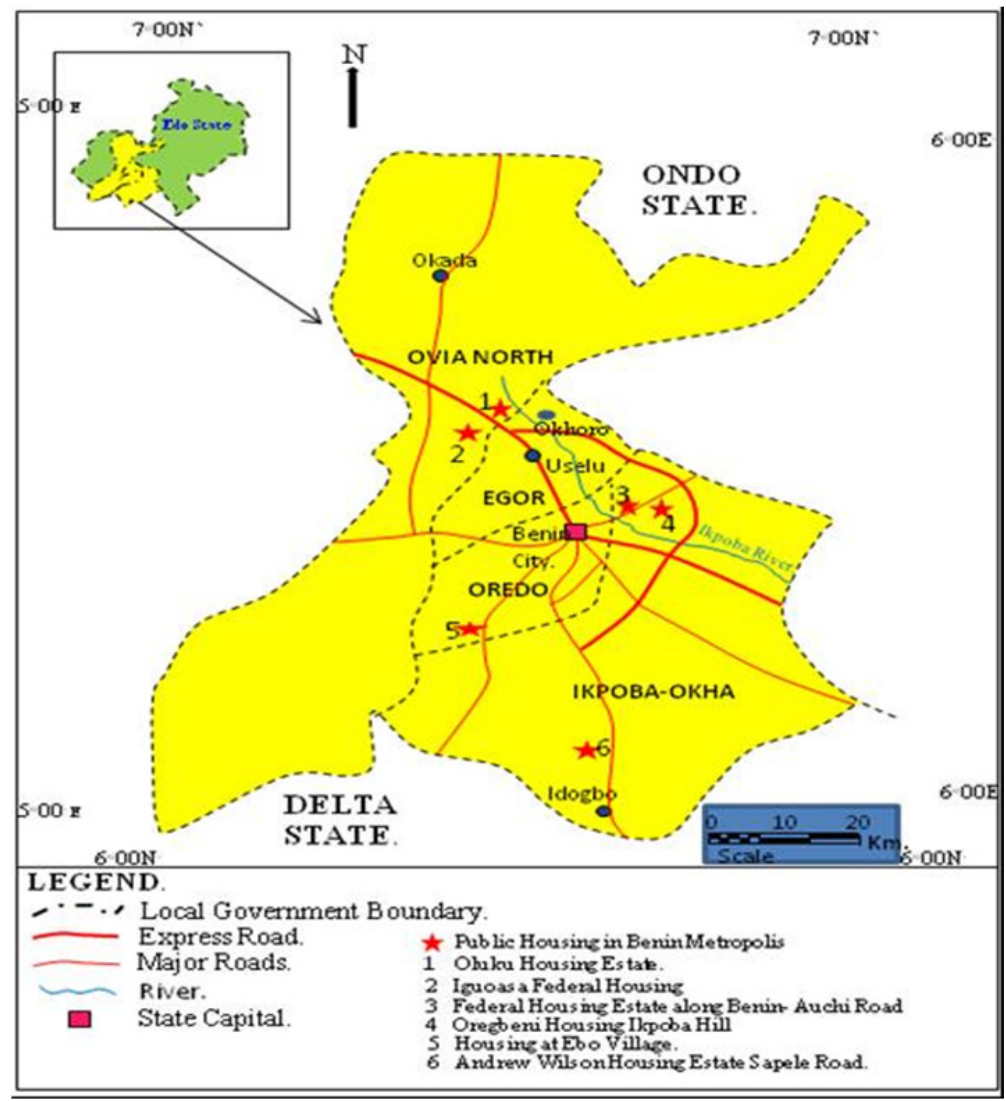

Figure 2: Location of Public Housing Estates in Benin City

Source: Cartography Studio, A. A. U. Ekpoma, 2014 


\section{Review of Related Literature}

The concept of housing satisfaction according to Bonaiuto \& Fornara (2017) cited by (Okoye, Odim \& Nwakwo, 2018) refers to an experience of pleasure or gratification a resident derives on or after dwelling in a particular place; (e.g., house or building, and building environment). Similarly, (Djebarni and Al-Abed 200o, p230) posit that housing satisfaction refers to "the degree of contentment experienced by an individual or family with regard to the current housing situation".

Djebarni \& AL-Abed (2000, p230) further opine that the concept of housing satisfaction has been used to achieve the following:

i. $\quad$ "A key predictor of an individual's perception of general quality of life;

ii. As an indicator of incipient residential mobility and hence capable of altering housing demands and affected neighbourhood changes;

iii. As an evaluative measure of judging the success of housing development by both the private and public sectors; and

iv. An assessment tool to measure residents' perceptions of inadequacies in their current housing environment with a view to improving the status quo."

Many researchers opine that housing satisfaction has aided to determine and assess the feelings and perception of residents of a particular housing units or the housing environment which are important parameters in predicting and measuring residents' perception of quality life. Similarly, Hui \& Yu (2009) opine that housing satisfaction provides researchers the opportunity to examine the gap that exists between residents housing needs and their desired expectation of what their current housing state of affairs and ideal housing situation should be.

The Relative Satisfaction Index (RSI) is used as an instrument for measuring satisfaction. It is an index for determining the level of contentment with housing. According to (Coker, Awokola, Olomolaiye, \& Booth, 2007); housing quality is nearly allied to quality of residential neighbourhood as it also mirrors the residents' quality of life and hence; their residential satisfaction. Housing quality is vital in housing satisfaction because it comprises housing attributes that assist it perform its important purpose of enhancing in more excellent way a more suitable living condition, healthy living that enhance psychological and physical well-being.

In the same vein, Vibka \& Combs (1991) note that been satisfied with ones residential neighbourhood environment is a key aspect of housing satisfaction. They posit that there are instances whereby residents ignore inadequacies of their housing units because of the satisfaction they derived from their neighbourhood environment. Dissatisfaction with neighbourhood environment according to Awotona, (1990) arises as a result of long distances travelled by residents and their children either to their school, place of work, health facilities, and place of worship. Housing estates located in the outskirt of city centres suffer this malady. In another study (Ozo, 1991; Bonnefoy, 2007) identified accessibility to public facilities such as transportation, communal and shopping centres and physical environment as predictors of neighbourhood satisfaction.

Previous studies (Weidemann; Anderson; Butterfield \& Donnel, 1982; Apparicio \& Seguin 2006) pointed out the important roles management of neighbourhood environment play in determining residents' satisfaction. Corroborating this Burby \& Rohe, 1989 argue that management services such as conflicts resolution, prompt dealing and resolution of the rules are enforced by the housing management as predictors of satisfaction with housing

Other studies in the area of housing and neighbourhood satisfaction have paid attention on the evaluation of housing unit as well as immediate external neighbourhood environment. Among these are Bonnefoy, 2007 which dwelt on social functionality of housing units, potential safety threats in housing environment. Other vital aspects in the evaluation of housing include; availability of parking lots, availability of playground, external lightning e.c.t (Olatubara \& Fatoye, 2007; Ha, 2008).

Furthermore, a study (Salleh, 2008) revealed that neighbourhood variables were prominent factors influencing the levels of housing satisfaction in Malaysia. Similarly, Olotuah (2007) study showed that age of buildings, use of toilets and frequency of collection of refuse were strong 
indicators of housing quality. From the above findings, it can be stated that housing and neighbourhood environment components are very significant factors that can make positive or negative contributions to residential satisfaction levels of residents.

\section{Research Methodology}

A comprehensive and well structured questionnaire was designed and used in interviewing respondents with the view to eliciting their perception of the housing and residential environment of the selected housing estates. The questionnaire was divided into two parts. The first has variables on the demographic and socio-economic characteristics of the residents. The second part is on residents' housing and neighbourhood environment variables. The variables include: allocation for recreation centres (RCT), condition of overcrowding (CO), refuse disposal (RD), level of noise pollution (LPN), clean kept surrounding (CKS), erosion effect (EE), quality of water (QW) and Cleanness of buildings (CLB).

The research employed field survey through the use of structured questionnaires, oral interviews and observation methods. The field work was carried out in 2018. The questionnaires were administered randomly to heads of households in the six selected estates, depending on the number of houses. The Survey covered all the six completed and occupied housing estates. A total number of 1200 questionnaires were administered but 1000 were completed and returned in useable form, which gives a completion rate of 83.3 percent.

Adequate cross-checking of respondents' answers was made in each case to ensure that the information volunteered by the respondents was reliable. The Relative Satisfaction Index (RSI) was computed. Furthermore, the data were presented in tables, bar charts and analysed descriptively. In addition, the Categorical Regression Analysis (CATREG) was also utilized.

\section{Presentation and Analysis}

Figure 3 shows the age pattern of the respondents across the estates. The figure reveals that residents less than zoyears are the least across the estates. Residents in Oluku Housing Estate have the highest number of residents within the Age range of 31-45 years. Residents in Oregebeni estate have the highest number of individuals with age from 6o- above.

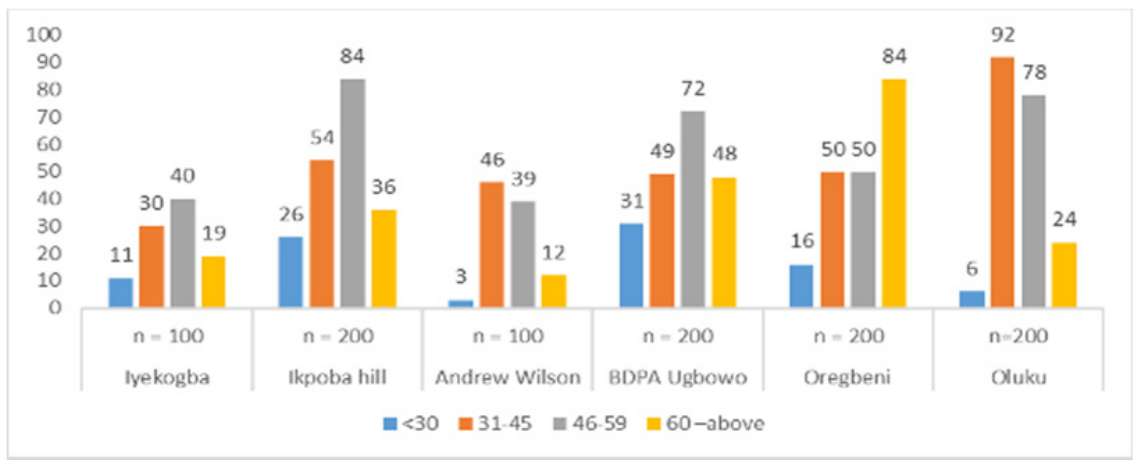

Figure 3: Age Distribution

Source: Field Work (2018)

Figure 4 shows the gender distribution of the respondents. The highest number of males is seen for residents in BDPA, Ugbowo and the lowest for Iyekogba, the highest for females is in oregbeni estate with the lowest in Andrew Wilson. 


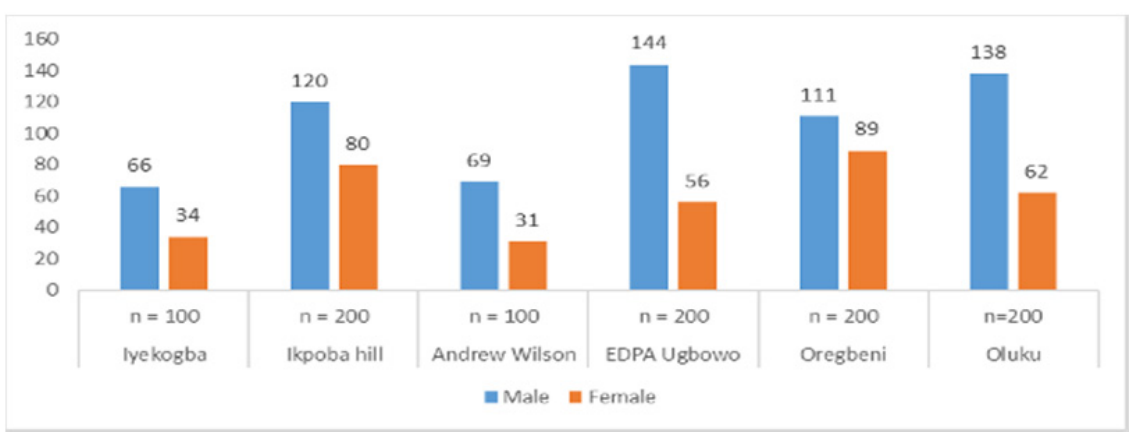

Figure 4: Gender Distribution

Source: Field Work (2018)

The educational qualification of residents as shown in figure 5 shows that EDPA estate has the most number of residents having $1^{\text {st }}$ degree. SSCE holders are highest for residents at in Ikpoba-hill while those with post-graduate degree appear are dominant in EDPA.

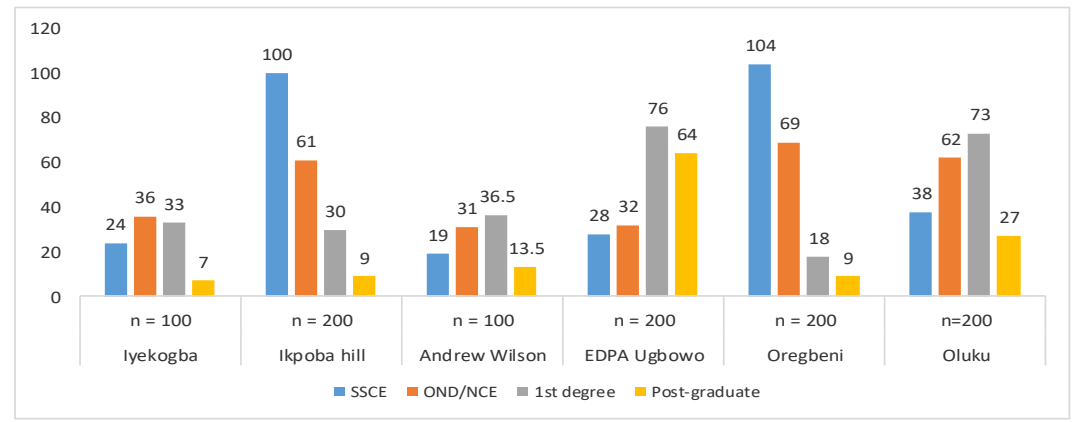

Figure 5: Educational Distribution

Source: Field Work (2018)

Type of occupancy shown in figure 6 reveals that owner-occupier is highest for residents in Ikpoba hill and lowest for Iyekogba while tenant-occupier is highest for residents in EDPA, Ugbowo.

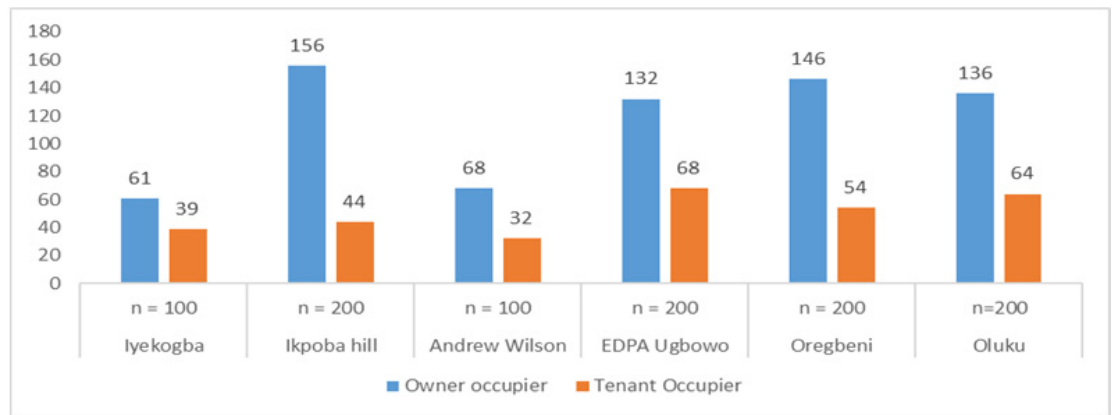

Figure 6: Occupier Status

Source: Field Work (2018) 
In evaluating the residents' satisfaction levels of the six housing estates, the Relative Satisfaction Index (RSI) scores are noted as indicated in table 1.

Table 1 shows the mean scores for estate environment indicators and the mean score provide an clue of the typical clustering of the reaction to everyone account and as observed; Allocation for Recreation Centre $(\mathrm{RCT})=\{2.8037\}$, Condition of Overcrowding $(\mathrm{CO})=\{2.8037)$ Refuse Disposal (RD) $=\{2.6578\}$, Level of Noise Pollution $(\mathrm{LNP})=\{2.8037)$, Clean Kept Surrounding $(\mathrm{CKS})=\{2.8037\}$, No Air Pollution $(\mathrm{NAP})=\{2.6578\}$, Cleanness of Building $(\mathrm{CLB})=\{2.8037\}$, Erosion Effect $(\mathrm{EE})=\{2.8037\}$ and Quality of Water $(\mathrm{QW})=\{2.6578\}$. All the indicators fall between the unsatisfied regions [2-2.99]. In conducting qualitative research as in the current study, there is the need in the direction of ensuring that the research instrument used in the study is reliable. In order to ascertain this, the scales used in the development of the questionnaire needs to be tested to ensure their reliability. For dependability of a multi item scale, the test of reliability needs to be ascertained (Peterson 1997). In this regards, the study utilizes the Cronbach Alpha test for reliability. This Alpha test for all the variables are above 0.70. Nunnally (1979) recommended 0.7 as an acceptable Alpha score.

As noted, the result of all the variables using the Cronbach alpha are greater than 0.70 . This authenticates that the concepts used for the study are reliable and that the variables are without a doubt measured what the study aimed to achieve.

Table 1. Descriptive Statistics for Estate Environment Indicators

\begin{tabular}{|l|c|c|c|c|c|}
\hline & MS Mean Score & $\begin{array}{c}\text { Standard } \\
\text { Error }\end{array}$ & $\begin{array}{c}\text { Standard } \\
\text { deviation }\end{array}$ & $\begin{array}{c}\text { Normality } \\
\text { Test }\end{array}$ & $\begin{array}{c}\text { Cronbach } \\
\text { Alpha }\end{array}$ \\
\hline Satisfaction with Estate environment & & & & & 0.901 \\
\hline Allocation for Recreation Centre(RCT) & 2.373 & 0.02851 & 0.90149 & 87.925 & \\
\hline Condition of Overcrowding(CO) & 2.891 & 0.03076 & 0.97266 & 94.384 & \\
\hline Refuse Disposal (RD) & 3.144 & 0.0307 & 0.97067 & 92.43 & \\
\hline Level of Noise Pollution(LNP) & 3.085 & 0.03339 & 1.05588 & 87.925 & \\
\hline Clean Kept Surrounding (CKS) & 2.856 & 0.03063 & 0.96861 & 94.384 & \\
\hline No Air Pollution (NAP) & 3.85 & 0.01969 & 0.62281 & 74.403 & \\
\hline Cleanness of Building (CLB) & 2.946 & 0.03082 & 0.9747 & 87.925 & \\
\hline Erosion Effect(EE) & 2.906 & 0.0302 & 0.95503 & 94.384 & \\
\hline Quality of Water (QW) & 2.476 & 0.02676 & 0.84625 & 64.54 & \\
\hline
\end{tabular}

Source: Field survey (2018).

Table 2 shows the residents' satisfaction levels. As for estate environment, the result revealed that there are variations in RSI scores across the environmental dimensions examined for both the older and relatively newer estates. For Iyekogba, results revealed that the inhabitants are satisfied with Allocation for Recreation Centre (RCT) and Condition of Overcrowding (CO) with RSI scores of 4.092 and 4.711 respectively. Residents of Andrew Wilson are satisfied with Allocation for Recreation Centre (RCT) and condition of Overcrowding (CO) with RSI scores of 3.448 and 3.018 respectively. Resident in Oluku indicates that they are satisfied with Allocation for Recreation Centre (RCT) and with RSI scores of 4.121 but fairly satisfied with Condition of Overcrowding (CO) with RSI score of 3.233. Residents of Andrew Wilson reveal that they fairly satisfied with Allocation for Recreation Centre (RCT) and with Condition of Overcrowding (CO) with RSI scores of 3.448 and 3.1018 respectively. Residents of Ikpoba Hill, BDPA and Oregbeni which are the older estates appeared fairly satisfied with Allocation for Recreation Centre (RCT) with RSI scores of 3.051, 3.381 and 3.333 respectively. Regarding condition of Overcrowding (CO) the RSI scores are 2.540, 3.532 and 2.591 which implies that residents in Ikpoba Hill and Oregbeni are dissatisfied while those in BDPA are fairly satisfied. With regard to Refuse Disposal (RD), the results revealed that the RSI scores for the residents in the comparatively older estates; Ikpoba Hill, BDPA and Oregbeni signifies that the inhabitants are discontented whereas for the moderately new ones; 
Iyekogba, Andrew Wilson and Oluku the RSI scores revealed that the residents are fairly satisfied. Regarding Level of noise pollution (NNP) Clean Kept Surrounding (CKS), it appears that residents of Iyekogba have the highest RSI scores of 4.041 and 4.402, which implies that residents are satisfied. Residents of Andrew Wilson and Oluku show RSI scores of 3.508, 3.163 and 3.264, 3.323 respectively and this suggest that the residents are fairly satisfied. For Ikpoba Hill and Oregbeni residents, the RSI score are 2.544, 2.442 and 2.513, 2.781 and this suggest that in relation to Level of Noise Pollution (LNP) and Clean Kept Surrounding (CKS) residents of both estates are dissatisfied. The reason for this could probably be because some of the estates are not properly maintained except lyekogba and EDPAUgbowo that exhibit serene environment as shown in plates (1-4).

Table 2: Satisfaction Index Scores of Estate Environment Variables across the Different Categories

\begin{tabular}{|l|c|c|c|c|c|c|c|c|}
\hline & $\begin{array}{c}\text { Iyekogba } \\
\mathrm{n}=100\end{array}$ & $\begin{array}{c}\text { Ikpoba } \\
\text { Hill } \\
\mathrm{n}=\mathbf{2 0 0}\end{array}$ & $\begin{array}{c}\text { Andrew } \\
\text { Wilson } \\
\mathrm{n}=100\end{array}$ & $\begin{array}{c}\text { BDPA } \\
\text { Ugbowo } \\
\mathrm{n}=\mathbf{2 0 0}\end{array}$ & $\begin{array}{c}\text { Oregbeni } \\
\mathrm{n}=\mathbf{2 0 0}\end{array}$ & $\begin{array}{c}\text { Oluku } \\
\mathrm{n}=\mathbf{2 0 0}\end{array}$ & $\begin{array}{c}\text { Cronbach } \\
\text { Alpha } \\
\text { test }\end{array}$ \\
\hline \multicolumn{7}{|c|}{ Estate environment } \\
\hline Allocation for Recreation Centre (RCT) & 4.092 & 3.051 & 3.448 & 3.381 & $3 . .333$ & 4.121 & \\
\hline Condition of Overcrowding (CO) & 4.711 & 2.540 & 3.018 & 3.532 & 2.591 & 3.233 & \\
\hline Refuse Disposal (RD) & 3.033 & 2.531 & 3.202 & 2.414 & 2.232 & 3.449 & \\
\hline Level of Noise Pollution (LNP) & 4.041 & 2.545 & 3.508 & 3.193 & 2.458 & 3.264 & \\
\hline Clean Kept Surrounding (CKS) & 4.402 & 2.442 & 3.163 & 3.513 & 2.513 & 3.323 & \\
\hline No Air Pollution (NAP) & 3.223 & 2.323 & 3.227 & 3.711 & 2.781 & 3.428 & \\
\hline Cleanness of Building (CLB) & 3.482 & 2.666 & 3.611 & 3.639 & 2.120 & 3.113 & \\
\hline Erosion Effect (EE) & 3.414 & 2.439 & 3.509 & 2.183 & 3.432 & 3.383 & \\
\hline Quality of Water (QW) & 3.842 & 3.232 & 3.430 & 3.401 & 3.594 & 3.722 & \\
\hline
\end{tabular}

Source: Field work (2018)

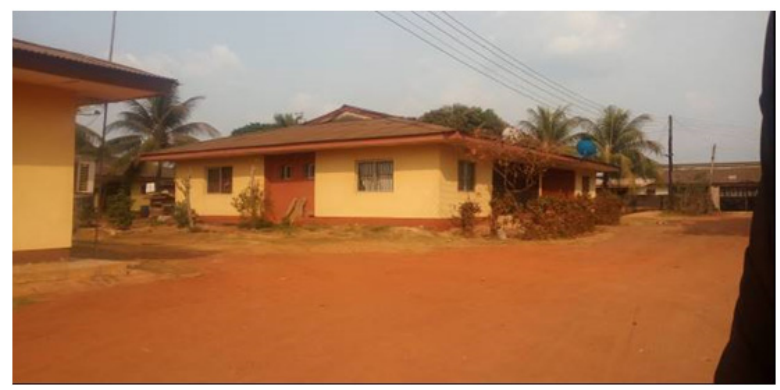

Plate 1- Showing environmental quality of a building at Andrew Wilson Housing Estate

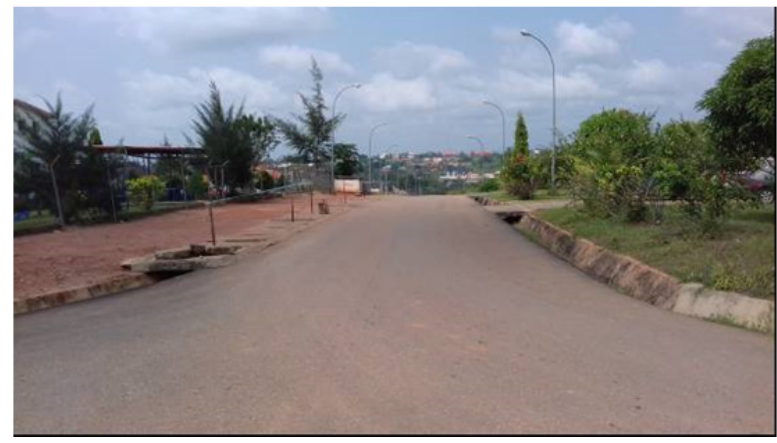

Plate 2- Showing environmental quality at Iyekogba Housing Estate 


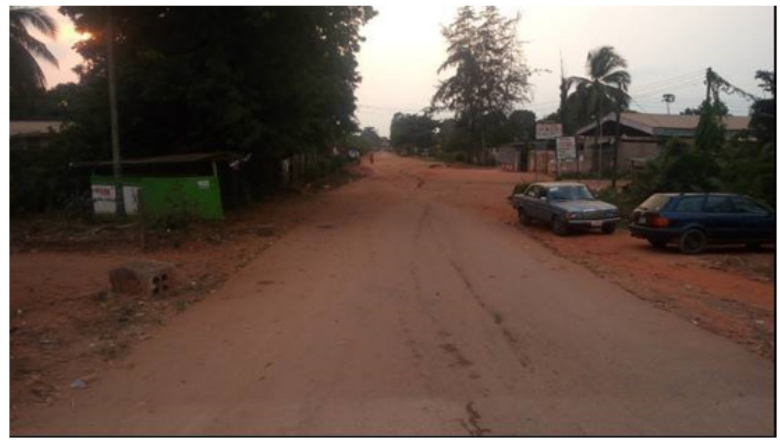

Plate 3- Showing environmental quality at EDPA Housing Estate, Ugbowo

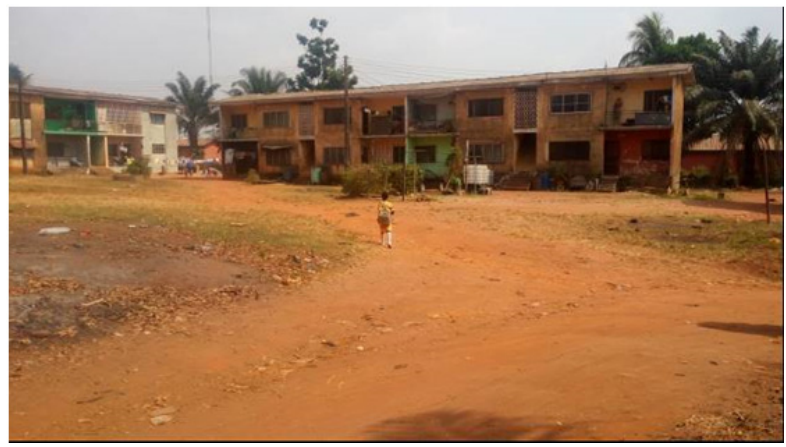

Plate 4- Showing environmental quality at FHA, Ikpoba Hill Housing Estate.

Evaluating the residents satisfaction with regards to Erosion effect (EE), Quality of Water (QW); the results showed that the RSI scores for the residents in Iyekogba, Andrew Wilson and Oluku are $(3.414,3.842)(3.509,3.430)$ and $(3.383,3.722)$ respectively which indicates that the residents are fairly satisfied while for the Ikpoba Hill, BDPA and Oregbeni, the RSI scores are $(2.439,3.232)(2.183,3.401)$ and $(3.431,3.594)$ respectively. The reason for the variations in the satisfaction indices could be probably attributed to the fact some of the estates have erosion problems because the roads are not paved and no side drainages for run-off water as shown in (plates 5-8).

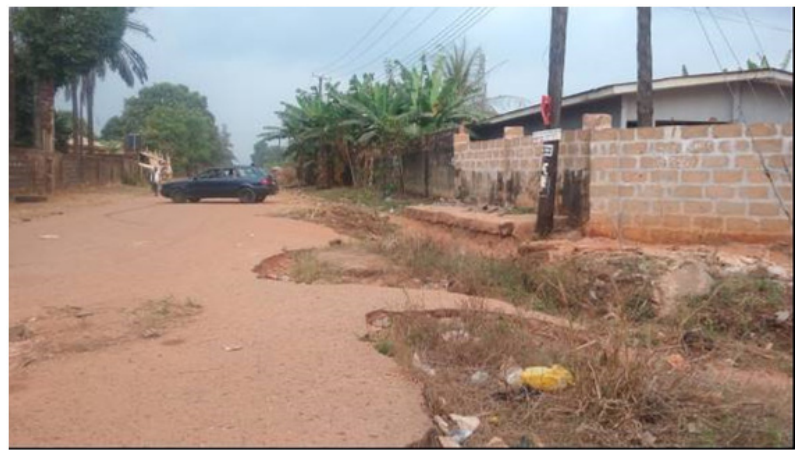

Plate 5. Showing the effect of erosion at EDPA Housing Estate, Ugbowo 


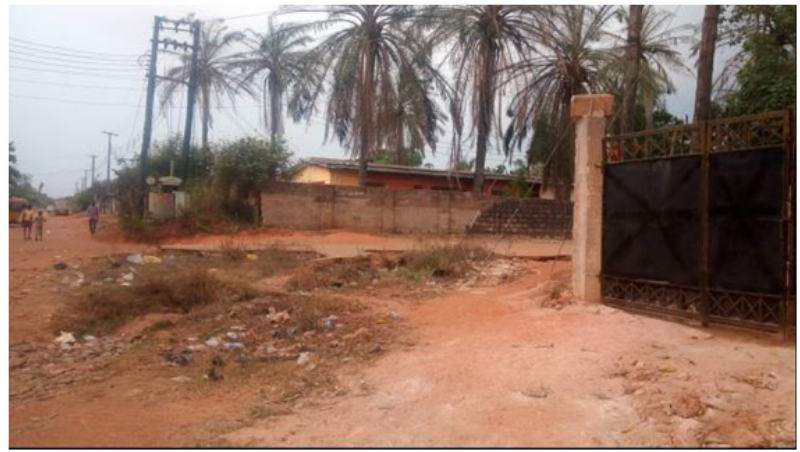

Plate 6. Showing the effect of erosion at EDPA Housing Estate, Ugbowo

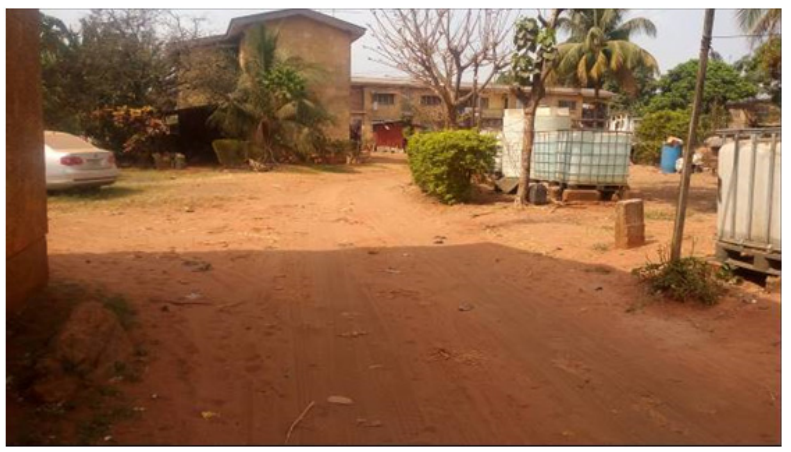

Plate 7. Showing the effect of erosion at FHA, Ikpoba Hill Housing Estate

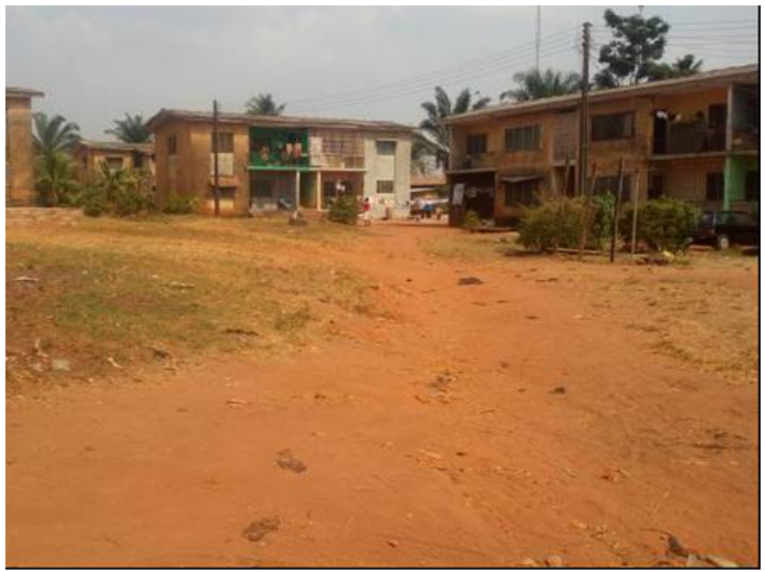

Plate 8. Showing the effect of erosion at FHA, Ikpoba Hill Housing Estate

On responses regarding quality of water, this is probably because the public water works have either stopped running or are not in existence. This condition is worse at FHA, Ikpoba Hill. In this housing estate, some residents provided private boreholes and sell water to other residents. This situation has resulted in so many storage tanks and "jerry cans" that litter the environment making is unsightly as shown in plates (9-12). 


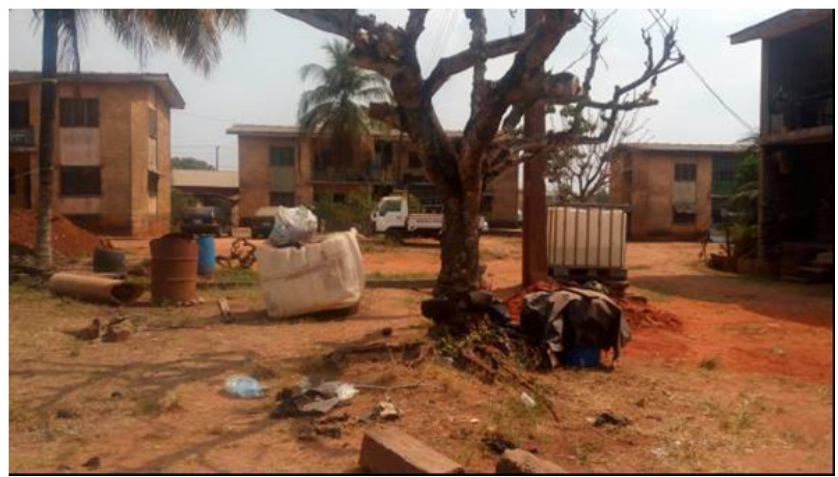

Plate 9. Showing Individual Water Tanks which implies severe water shortage at FHA Housing Estate.

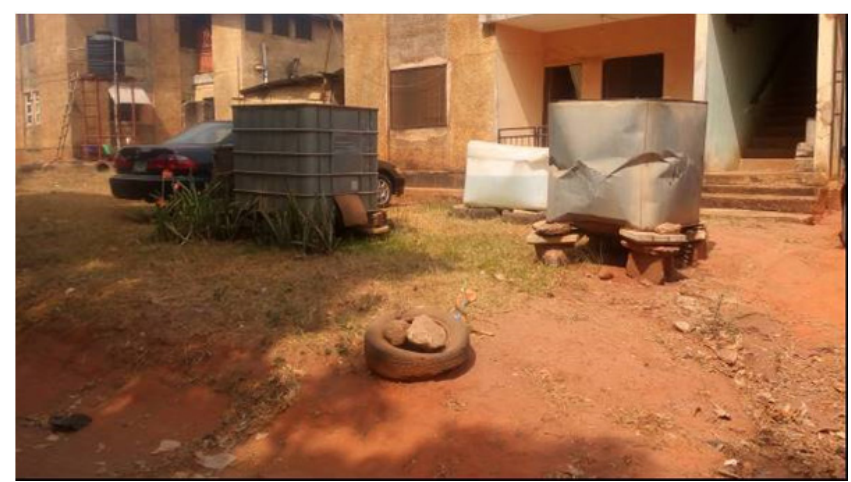

Plate 10. Showing Individual Water Tanks which implies severe water shortage at FHA Housing Estate.

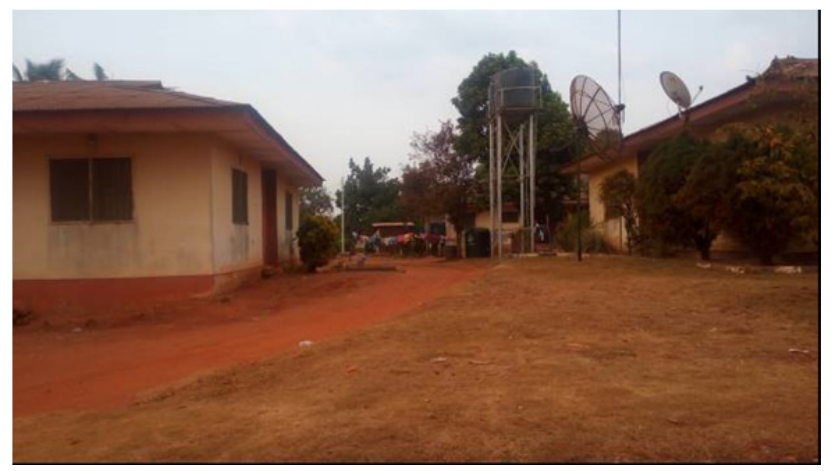

Plate 11. Showing Individual Water Tanks which implies severe water shortage at Andrew Wilson Housing Estate 


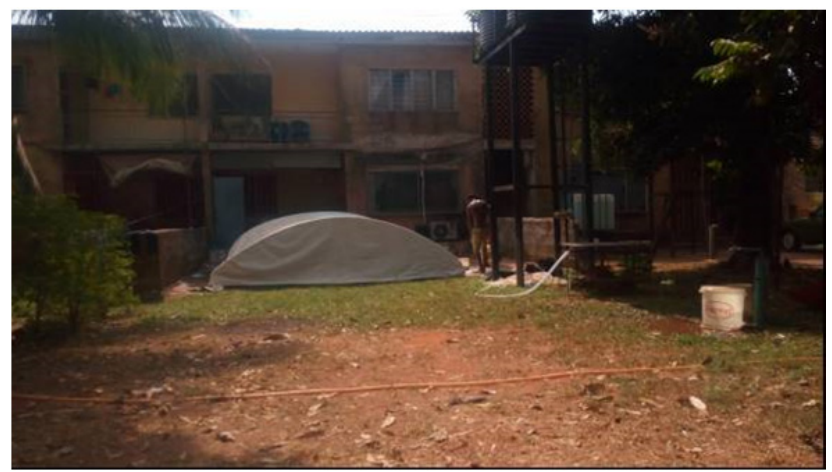

Plate 12. Showing Overhead Water Tanks which implies severe water shortage at FHA Housing Estate

The Categorical Regression Analysis (CATREG) shown in Table 3 was utilized to examine if significant correlation subsists among the estate environment and residents' levels of satisfaction. As observed, the coefficient of determination $\left(\mathrm{R}^{2}\right)=0.623 \%$, Adj $\mathrm{R}^{2}=0.605 \%$. These values suggest that the regression model and by implication estate environment indicators explains about $62.3 \%$ of residual difference in occupants' satisfaction through an adjusted value of $60.5 \%$ subsequent to calculating for degrees of freedom. The coefficient of estate environment is 0.0542 which prove that the estate environment has a positive outcome on satisfaction level of residents as it is significant at $5 \%(\mathrm{p}=0.000)$.This entails that the estate environment has a strong positive sway on levels of satisfaction. This finding is in agreement with Ogu (2002), van Kamp et al (2003), Jiboye (2010) and Gbakeji (2014).

Table 3: Categorical Regression between RSI and Estate environment

\begin{tabular}{|l|c|c|c|c|}
\hline \multicolumn{2}{|c|}{} & $\mathrm{R}^{2}$ & Adjusted $^{2}$ & \\
\hline \multicolumn{2}{|c|}{} & 0.623 & 0.605 & \\
\hline Independent variable & Coefficient & Standard error & Df & Sig \\
\hline Estate environment & 0.0542 & 0.192 & 2 & 0.000 \\
\hline
\end{tabular}

Source: Field study, 2018. Dependent Variable: RSI, Predictor: Estate environment.

\section{Conclusion}

This study was designed to examine and analyse the residents' satisfaction levels with housing and residential neighbourhood environment of six housing estates in Benin City. Findings of the study showed that there are variations in Relative Satisfaction Index (RSI) scores across the environmental dimensions examined for both the older and relatively newer estates. Factors responsible were identified. For the relatively newer estates such as Iyekogba, Oluku and Andrew Wilson results revealed that the inhabitants are quite pleased with Allocation for Recreation Centre (RCT) and condition of Overcrowding (CO) with RSI scores ranging from 3.00-4.711 while those for the older estates such as Ikpoba Hill, BDPA and Oregbeni also appeared fairly satisfied 3.00-3.5. Regarding Condition of Overcrowding (CO), Refuse Disposal, (RD), Level of Noise Pollution (LNP), Clean Kept Surrounding (CKS), Erosion Effect (EE), Quality of Water (QW); we find that the RSI scores for the residents in Iyekogba, Andrew Wilson and Oluku are ranked higher indicating better satisfaction levels when compared to the RSI scores for the older estates. The estate environment was found to have a significant impact on the residents' satisfaction levels. Observations during the fieldworks 
showed perceived substandard infrastructure in some of the housing estates.

\section{Recommendation}

Based on the findings and conclusion, the following recommendations are suggested;

7.1 There is the need to address environmental problems highlighted in the Summary of Findings. This is with a view to achieve a quality and a satisfactory housing environment, Government and policy makers need to attend urgently to this. Government may not be able to take direct responsibility over private properties but improvement on facilities may be done. One way to achieve this may be through the public-private partnerships, where and when private organizations play complementary roles with the government and vice versa.

7.2 There is the need to sustain the provision and maintenance of basic facilities. Consequently the inhabitants and management of these estates should imbibe the culture of regular maintenance with a view to sustaining the quality of infrastructural facilities and physical improvement of the housing stocks. Furthermore, residents should be enlightened and educated on the importance of maintenance and its effectiveness as a cost reduction strategy and a way of prolonging the physical life of building structures and facilities. This will help to achieve proper maintenance of public facilities, and thereby promote residential satisfaction in Benin City. This may enhance both qualitative and quantitative housing delivery.

7.3 There is the need for managers of these housing estates to urgently address the erosion menace ravaging some of the housing estates. This is to forestall further and future damages to the neighbourhood environment and landscape. Government Policy Makers, Architects, Planners and Developers should ensure that future housing estates need to be developed with all the essential ancillary and infrastructures such as tarred roads, adequate drains and culverts, gutters and services that would enhance neighbourhood environmental quality.

7.4 There is the need for observance of planning rules and regulations. To increase residential and neighbourhood satisfaction, there should be rules for planning that should be implemented and will be administrated by government laws enforcers and not by individuals. This will check indiscriminate dumping of refuse and other activities that devalue environmental quality of public housing estates and hence residents' satisfaction.

\section{References}

Agbola. T. (2005): "The housing debacle". Inaugural lecture delivered at the University of Ibadan, August 2005.

Akinbode A. (2000): Provision of Adequate Housing in Developing Countries: A Theoretical Consideration in Osuide S.O. (Ed.) Proceedings of the National Seminar on Population Growth Architecture and the Environment $21^{\text {st }}-22^{\text {nd }}$ February, 2000. $109-118$.

Akindele, O. A, Ojo, T, \& Abolade, O.(2014): Perceived housing satisfaction in public estates of Osogbo, Nigeria. Journal of Geographical and Regional Planning, 2014. 7(9) 185-191.

Aluko O. (2012): "Housing Construction in the Built Environment: A case of Urban Growth in Metropolitan Lagos", GRP Journal of Environment Planning and Management, Vol. 5, pp. 114-122

Apparicio, P. \& Seguin, A. (2006). Measuring the accessibility of services and facilities for residents of public housing in Montreal. Urban Studies 43(1) 187-211.

Awotona A.A. (1990). Nigerian Government participation in housing 1970-1980. Habitat International, 14(1).

Asikhia M. O \& Ajirioghene, U.E. (2012): "Geospatial Variation in Housing Quality in Ekosodin and Evbuomore Communities in Benin City, Edo State, Nigeria”, GRP Journal of Environmental Planning and Management, $5,26-35$.

Bonaiuto, M; Fornara, F. (2017). Residential satisfaction and perceived urban quality. Neuroscience and Biobehavioural Psychology, Elsevier.

Bonnefoy, X. (2007). Inadequate housing and health: and overview. International Journal Environment and Pollution 30(3/4): 411-429 
Burby \& Rohe. (1989). Deconcentration of public housing; Effects on residents' satisfaction with their living environment and their fear of crime. Urban Affairs Review 25, 117-141.

Coker, A.O.; Awokola, O.S.; Olomolaiye, P.O. and Booth, C.A. (2007). Challenges of urban housing quality and association with neighbourhood environments: insights and experiences in Ibadan City, Nigeria. JEHRJournal of Environmental Health (7) $1 . \quad$ Available Online at http://www.Cieh.org/JEHR/challenges_urban_housing.htm. accessed on February 4, 2008.

Dimuna K.O. (2011). The social effect of the build environment. A case study of selected buildings in Benin City Nigeria. Journal of Human Ecology. 34 (3) 189-196.

Dimuna K.O. (2017). A study of residents' satisfaction with public low-cost housing estates in Benin City, Edo State, Nigeria. Unpublished PhD Thesis submitted to School of Postgraduates Studies, Ambrose Alli University, Ekpoma, Edo State, Nigeria.

Djebarni, R. and Al-Abed, A. (200o). Satisfaction level with neighbourhoods in low-income public housing in Yemen. Property Management, 18(4): 230-239.

Fatoye, E.O \& Olatubara, C.O.,(2006). An evaluation of students' satisfaction with on campus housing in Nigeria tertiary institution. A case study of University of Ibadan student hostel Journal of Nigeria Institution of Quantity Surveyor 54 (4):14-21.

Gbakeji, J.O. (2006): Neighbourhood Satisfaction, the perception of places and intra-urban residential mobility: An example from the Warri Metropolis, Delta State, Nigeria, The Built Environmental Journal, 2(3) 32-36.

Gbakeji, J.O. (2014): Analysis of residential Satisfaction in some residential neighbourhood in Benin City, Nigeria. Journal of Civil and Environmental Engineering, 2(1) 1-10

Ha, S-K (2008). Social housing estates and sustainable community development in South Korea, Habitat International, (32): 349-363.

Henilane, I (2016): Housing Concepts and Analysis of Housing classification. Baltic Journal of Real Estate Economics and Construction Management. 4, 168-179. November, 2016.

Hui ECM, Yu KH (2009). Residential mobility and aging population in Hong Kong. Habitat International (33):10-14

Ibem, E.O. \& Aduwo E. B (2013). Assessment of residential satisfaction in public housing in Ogun State, Nigeria. Habitat International, 40: 163-175.

Ibem, E.O. and Azuh D.E (2014). Satisfaction with public housing among urban women in Ogun State, Nigeria. Covenant Journal of Research in the Built Environment (CJRBEN 1 (2)

Jiboye, A, (2010). Evaluating users' household-size and housing quality in Osogbo, Nigeria Ethiopian Journal of Environmental Studies and Management. 3 (2):77.

Mabogunje, A.L, (2003). The new mass housing and urban development policy: social and economic impact in Aribigbola, A.(ed.) (2008). Being text of a public service lecture delivered to the top echelons of the federal civil service, Abuja, Nigeria.

Mohit, M.A., Ibrahim, M. \& Rashid, Y.R. (2010). Assessment of residential satisfaction in newly designed public low-cost housing in Kuala Lumpur, Malaysia. Habitat International, 34(1), 18-27.

National Population Commission (2006). Population and housing census of the Federal Republic of Nigeria priority tables (vol. 1)

National Population Commission (NPC) 1991.

Nunnally, L. (1979). Cronbach alpha statistics: retrieved from www.ssrn.com on $31^{\text {st }}$ May, 2018.

Ogu, V. I, (2002). Urban residential satisfaction and the planning implications in a developing world context: the example of Benin City, Nigeria. International. Planning Studies, (7):37-53.

Okoye K.C; Odim O.O; Nwankwo S.I. (2018). Evaluating the physically challenged satisfaction with modification of rest rooms in public housing estates in Yola. Journal of Nigerian Institute of Architects Abia State Chapter (J-NIAABSC). 1(3)143-156

Olatubara, C.O. \& Fatoye, E.O. (2007). Evaluation of the satisfaction of occupants of the Abesan public low-cost housing estate in Lagos State, Nigeria. The Nigerian journal of Economic and Social Studies 49 (1).

Olatubara, C.O. \& Adegoke S.A.O. (2007). Housing maintenance. In Agbola T, Egunjobi L \& Olatubara C.O (eds). Housing Development and Management: A Book of Readings. Department of Urban and Regional Planning, University of Ibadan, Nigeria. Malijoe Sofprint, Ibadan. Pg 391-418.

Olotuah, A.O. (200o). Evaluation of Suburbia Housing Conditions in Akure, Nigeria, African Journal of Development Studies 2(1\&2) 165-173

Olotuah, A.O. (2002). Towards Meeting Low-Income Earners Housing Needs in Ado-Ekiti, Nigeria Journal of the Nigerian Institute of Town Planners, XV, 15-24,

Olotuah A.O. (2007). Housing quality in suburban areas: An empirical study of Oba-Ile, Nigeria, Dimensi Teknik Arsitektur, 34(2): 133-137.

Ozo, A. O. (1991). Low cost urban housing strategies in Nigeria. Habitat International 14(1):51-54 
Peterson R.A. (1994). A meta-analysis of Cronbach's coefficient apha. Journal of Consumer Research 21 (2) $381-391$.

Salleh, A.G. (2008). Relationship between landscape structure and neighbourhood satisfaction in urbanized areas. Habitat International (32) 485-493

The Columbia Encyclopedia, Sixth Edition, 2005. Columbia University Press. Retrieved $18^{\text {th }}$ February, 2007.

Ukoha, O.M. and Beamish, J.O (1997) Assessment of residents' satisfaction with public housing in Abuja, Nigeria. Habitat International 21(4) 445-46o.

UNCHS (2001). An urbanizing world: global report on human settlement 2001. Oxford: Oxford University Press.

UN-HABITAT. (2006). Nigeria. In National trends in housing - Production practices, Vol. 4, Nairobi: United Nations Centre for Human Settlements.

Van Kamp. I, Liedelmeijen. K, Marsman. G \& Augustinio de Hollande (2003). Urban environmental quality and human well-being: Towards a conceptual framework and demarcation of concept; a literature study. Landscape and urban planning 65: 5-18.

Vrbka, S. J. \& Combs, E. R. (1991). Predictors of neighbourhood and community satisfaction in Rural Communities. Referred papers of the American Association of Housing Educators Annual Conference, Durham, NH.

Weidermann, S., Anderson, J. R., Butterfield, D. I \& O’Donnell, P.A. (1982). Residents' perceptions of satisfaction and safety. A basis in multifamily housing Environment and Behaviour 14(6):695-724.

WHO (1961). Expert Committee on the Public Aspects of Housing, Technical Report Series No. 225. 